\title{
Tourism Viability Status of Kwa Falls Ecotourism Site of Aningeje Rural Community, Cross River State, Nigeria
}

\author{
Eneyo V. B. ${ }^{1,{ }^{*}}$, Attah F. M. ${ }^{2}$, Antai A. S. ${ }^{3}$, Adie H. I. ${ }^{4}$, Ochiche C. A. ${ }^{5}$ \\ ${ }^{1}$ Department of Tourism Studies, University of Calabar, Calabar, Cross River State, Nigeria \\ ${ }^{2}$ Department of Sociology, University of Calabar, Calabar, Cross River State, Nigeria \\ ${ }^{3}$ Department of Economics, University of Calabar, Calabar, Cross River State, Nigeria \\ ${ }^{4}$ Department of Public Administration, University of Calabar, Calabar, Cross River State, Nigeria \\ ${ }^{5}$ Department of Geography and Environmental Science, University of Calabar, Calabar, Cross River State, Nigeria
}

Received November 2, 2021; Revised January 12, 2022; Accepted February 8, 2022

\section{Cite This Paper in the following Citation Styles}

(a): [1] Eneyo V. B., Attah F. M., Antai A. S., Adie H. I., Ochiche C. A. , "Tourism Viability Status of Kwa Falls Ecotourism Site of Aningeje Rural Community, Cross River State, Nigeria," Environment and Ecology Research, Vol. 10, No. 2, pp. 125 - 132, 2022. DOI: 10.13189/eer.2022.100202.

(b): Eneyo V. B., Attah F. M., Antai A. S., Adie H. I., Ochiche C. A. (2022). Tourism Viability Status of Kwa Falls Ecotourism Site of Aningeje Rural Community, Cross River State, Nigeria. Environment and Ecology Research, 10(2), 125 - 132. DOI: 10.13189/eer.2022.100202.

Copyright $\odot 2022$ by authors, all rights reserved. Authors agree that this article remains permanently open access under the terms of the Creative Commons Attribution License 4.0 International License

\begin{abstract}
The tourism viability status of an eco-tourism site is distinctively an assessment of the tourist attractions that have potential for a given destination. It evaluates the prospects of a tourism destination and confirms whether the tourism site is functioning and its contributions to the host destination's sustainable economic growth. This study assesses the tourism viability status of the Kwa Falls eco-tourism site of Aningeje rural community, Cross River State, Nigeria. The objectives were to evaluate tourist perception of the study area and the patronage level across different years (2011-2020). The study took a qualitative approach and used stratified random sampling to select respondents, while data was collected using a simple random sample procedure. The study reveals that the study area is still viable, attractive, and unique, and tourists are still visiting the site even though there is a decline in the number of visitors. The result further reveals that from 2011 to 2015, the number of tourists visiting Kwa Falls has increased, and from 2016 to 2020, the study area experienced a sharp decline in the volume of visitors at the site. The first hypothesis shows significant variation in tourists' perception of Kwa Falls eco-tourism sites. The second hypothesis also offers a substantial variation in patronage status in the study area across the years. The study concludes that the government and other
\end{abstract}

stakeholders should provide subvention as well as other necessary support services and facilities at the site.

Keywords Tourism Viability, Kwa Falls Ecotourism Site, Aningeje, Tourism Potentials

\section{Introduction}

The tourism viability status of an eco-tourism site is distinctively an assessment of the tourist attractions that have potential for a given destination. It evaluates the prospects of a tourism destination and confirms whether the tourism site is currently functioning or viable and its contributions to the host destination's sustainable socio-economic growth. The study of tourism viability status of eco-tourism sites was no panacea in the twentieth century. Instead, it showcases the current status of any eco-tourism potentials under research. Tourists' long-term expansion benefits the economy and society, and the long-term use of tourism resources and goods is achieved by an in-depth analysis, understanding, and management of tourism demand [1]. On the other hand, the tourism industry development is a robust process of coordinating 
tourism assets or resources to meet the needs and inclinations of genuine and possible tourists [2].

People have considered an eco-tourism site as a viable economic venture throughout history [3]. If properly managed, they can contribute immensely to a substantial influx of domestic and international niche tourists attracted by the tourism potentials of the sites for sightseeing, religious conviction, leisure, recreation, and others. The viability of this sector has resulted in the emergence of various tourism ventures and initiatives across the globe. These ventures include tourism sites, cultural/traditional artefacts, hotels and accommodations, transport services, travel services/agencies, tour guides, medical services, and many other hospitality services [4]. Tourists rely on these support services provided within the different tourism destinations, creating a symbiotic relationship between tourists and the travel industry. This adequate provision of the services attracts more visitors and opens up the sector for job creation, income generation, business opportunities, and other socio-economic benefits and opportunities that it can bring.

Recently, scholars have opined that a viable eco-tourism site has the viability to boast the economic resources of many nations of the world through venture investments and the provision of support services within and around its environs [5]. Others opine that successful or viable eco-tourism and protected area show the functionality of the site (during peak and off-peak periods), a steady influx of potential tourists/visitors, effective management of the site by the government and other stakeholders for tourists' enjoyment and the site protection in perpetuity [6]. It is essential to check the viability of an eco-tourism site and its potentials and evaluate the associated impact of visitors at the site.

Furthermore, Nigeria is known for its rich eco-tourism potentials [7]. Thus, from the Northern region to the southern part of the country, there are renowned eco-tourism sites (such as Kiri dam, Enemabia warm spring, Katsina-Ala River, Laffy falls, Agbokim falls, Kwa Falls, Doma dam, Mayank waterfalls, Ipaleiioro waterfalls, Fari Ruwa waterfalls, and Aesop falls) [8]. They are varieties of attractions that are viable and still working (functional) [9]. Most of these ecological areas attract millions of domestic and foreign tourists each year $[10,11]$ Apart from the attractions, most visitors, in most cases, are usually eager to participate in the vast array of activities available and to view the serene environment and its natural features at the sites. Further studies have revealed that most eco-tourism rural entrepreneurship, such as the clustering of small and medium scale businesses within and around eco-tourism sites, has contributed to the site's high demand by their visitors [12, 13]. Moreover, the government and other stakeholders' development and growth of most eco-tourism sites have impacted the overall development of most rural communities through the provision of physical facilities like good road networks, communication facilities, transportation facilities, and other basic facilities on the site $[14,15]$. The growth and development have also attracted foreign investors and other stakeholders to invest in the sector. In the same vein, it has triggered those communities' socio-economic expansion, leading to spillover effects on the state's economy through payment of taxes, transportation fare, communication services, banking services, security, and other benefits $[16,17]$. More so, numerous visitors from far and near flock to the site for different reasons ranging from leisure, relaxation, recreation, and other reasons.

Over the years, the Cross River State has taken giant strides in developing the tourism sector by developing numerous private and government eco-tourism prospects. The tourism prospects include Coercopan, Cross River national park, Drill ranch, Oban hill, Obudu cattle ranch, Agbokim waterfalls, Kwa Falls, Nkarasi monoliths, Rock with footprints, Afi mountain resorts, Marina resorts, among others [18, 19]. The state government also put infrastructures that attract tourists, such as the cable car in Obudu cattle ranch, canopy walkways in Afi Mountain, and others [20]. The provisions of tourism attractions have made Cross River State a premier tourism destination in Nigeria. Kwa Falls is one of the hubs of tourist attractions and one of the eco-tourism developments strides of the state. And eco-tourism depends on natural resources without destroying the environment. The negative impact is being minimized, reinforcing the protection of nature and culture while at the same time actively contributing to the economic well-being of the host communities and generating revenue for the government [21].

Several tourists have visited the Kwa Falls eco-tourism site; their visits may stimulate the economic development of the state and social well-being of the people. Studies have shown that visitors' influx and patronage of the waterfalls have tremendously increased the popularity of the area and the visibility on the national, regional, and even global scale $[22,23]$. The number of tourists expected steadily increased over the years, more economic opportunities are expected, and most tourist destinations are inclusively providing economic opportunities for the host communities [24, 25]. Other stakeholders providing services re-direct their efforts to improve their services, focusing on satisfying the needs of tourists and understanding their demands. Enhancing the potential of tourism assets such as waterfalls entails collecting a wide range of information to measure changes that have taken place over the years. Such analysis indicates many issues, such as the number of tourists' arrivals, the income generated, employment opportunities, and other economic activities. It is envisaging that this will lead to management of the sites and their potentials so that the socio-economic and aesthetic necessities can be satisfied while keeping up with the socio-cultural integrity, biological variety, fundamental ecological processes, and life support systems. Thus, there are numerous researches on tourists' participation, plastic waste disposal, tourism support services, urban development, and tourism development [26, 
$27,28,29,30]$. However, there is limited, or no study on the subject matter. This study seeks to assess the tourism viability status of the Kwa Falls eco-tourism site in the Aningeje rural community of Cross River State, Nigeria.

\section{Materials and Methods}

The study was carried out in Kwa Falls ecotourism site, Aningeje rural community, Akamkpa Local Government Area of Cross River State, Nigeria. Kwa Falls lies between longitudes $8^{\circ} 35^{\prime} 0^{\prime \prime}$ ' and $8.58333^{\circ}$ East of the Greenwich Meridian and within latitude $5^{\circ} 25^{\prime} 0^{\prime \prime}$ and $5.41667^{\circ}$ north of the Equator. The study area is one of the areas designated as one of the biodiversity hotspots in the world and has one of the largest rainforests in the state. Akamkpa Local Government Area houses numerous animal species such as bush pigs, buffalo, deer, and monkeys. Akamkpa has many tourist attractions, including Cross River National Park, the Oban Hills, Kwa Falls, Oban Forest, the Cercopan site, and numerous eco-tourism sites. Many visitors usually visit the area during their leisure time to participate in recreational activities and other purposes.

\section{Methodology}

We used a case study research approach in this investigation. Tourist perceptions and patronage levels of Kwa Falls eco-tourism locations were among the data sources used in this study. We gathered the information for this study from both primary and secondary sources. The major sources of data collection were data acquired directly from the field through field observation, questionnaires, and respondent interviews. The researchers adopted the Participatory research method through Key Informant Interview (K11) to guide the interview sessions with the aid of a semi-structured checklist. The researchers obtained secondary data sources from the literature, maps and government gazette and records of visitors to Kwa Falls, among others. In addition, the study elicited information on tourists' patronage level from the history available in the study location. For the hypothesis test, the researchers gathered data quarterly and summarized the data yearly as presented and described in the result. The study population includes visitors of various categories, including international, national and local tourists, managers and tour guides.

Stratified random sampling initially was used to choose the number of respondents, followed by a simple random sample method to administer a questionnaire for data collection. The average annual patronage of the Kwa Falls as estimated from the daily tourists' visit is 365 tourists per year. Adopting Fifty per cent (50\%) of the yearly patronage was the sample size for the study. The $50 \%$, which is half of the 365 annual means of tourists, was chosen to accommodate the various views and perceptions of the tourists, provide a more accurate mean value, reduce error, and enhance accurate results. Moreover, to accommodate non-response and meet the minimum sample size, we added $28 \%$ to the $50 \%$ sample size. Thus, this enabled us to select a total of 235 respondents for the administration of the questionnaire. We retrieved 202 copies of the questionnaire from the field out of this number. We kept the copies of the questionnaire at the Kwa Falls eco-tourism site for the tour guides to administer to tourists. The information gathered for this study were all presented and analyzed using descriptive and quantitative methods. Among these is the usage of mean percentages in tables. The hypothesis testing was through an inferential statistical technique such as the Kruskal -Wallis test. The hypotheses were formulated in null forms and stated as follows:

Ho: There is no significant variation in tourists' perception of Kwa Falls ecotourism sites.

Ho: There is no significant variation in the status of patronage in the study area across the years

\section{Result and Discussion}

The data in Table 1 shows tourists' perception of the Kwa Falls ecotourism site in Aningeje rural community, Cross River State, Nigeria. In this study, we analyze tourists' perception based on some indicators for the working of ecotourism sites. Table 1 presents the perspective of the tourists. Based on workability, $40 \%$ of the respondents opined that Kwa Falls is still working, 36\% opined that it is not working, while $23.8 \%$ did not respond. Regarding visitors' patronage, the highest proportion (50\%) believed there was no increase in the visitors' influx to the site. This means that there is a low level of patronage. Also, $58.4 \%$ added that there is no increase in infrastructures, in the uniqueness of the Kwa Falls environment, $90.6 \%$ of the respondents affirm that the domain is unique. The attraction of the Kwa Falls shows that the climate is attractive, as indicated by $88.6 \%$. Other variables include accessibility to the site, security of the area, low cost of the tour, popularity; the recommendation for other tourists also shows a positive response.

The first hypothesis states that there is no significant variation in tourists' perception of Kwa Falls ecotourism sites. The researchers decided to use data from Table 1 and Kruskal -Wallis test to assess variations in tourists' perception of the study area. As shown in Table 2, the analysis result is descriptive of the set of data employed for the analysis. Table 3 shows a variation in the mean rank of visitors' perception. 
Table 1. Tourists perception of Kwa Falls Ecotourism Site

\begin{tabular}{|c|c|c|c|c|c|c|c|c|c|}
\hline S/N & Tourist Perspective & Yes & $\boldsymbol{\%}$ & $\mathbf{N o}$ & $\boldsymbol{\%}$ & Indifferent & $\boldsymbol{\%}$ & Total & $\boldsymbol{\%}$ \\
\hline 1 & Workability & 81 & 40.1 & 73 & 36.1 & 48 & 23.8 & 202 & 100 \\
\hline 2 & Increase visitors patronage & 83 & 41.1 & 101 & 50 & 18 & 8.9 & 202 & 100 \\
\hline 3 & Increase in Infrastructure & 57 & 28.2 & 118 & 58.4 & 27 & 13.4 & 202 & 100 \\
\hline 4 & Unique environment & 183 & 90.6 & 11 & 5.4 & 8 & 4 & 202 & 100 \\
\hline 5 & Attraction & 179 & 88.6 & 18 & 8.9 & 5 & 2.5 & 202 & 100 \\
\hline 6 & Increase in goods and services & 81 & 40.1 & 88 & 43.6 & 33 & 16.3 & 202 & 100 \\
\hline 7 & Accessibility to the site & 147 & 72.8 & 53 & 26.2 & 2 & 1 & 202 & 100 \\
\hline 8 & Security of the area & 98 & 48.5 & 86 & 42.6 & 18 & 8.9 & 202 & 100 \\
\hline 9 & Low cost of tour & 85 & 42.1 & 72 & 35.6 & 45 & 22.3 & 202 & 100 \\
\hline 10 & Popularity & 129 & 63.9 & 70 & 34.7 & 3 & 1.5 & 202 & 100 \\
\hline 11 & Recommended to others & 112 & 55.4 & 71 & 35.1 & 19 & 9.4 & 202 & 100 \\
\hline
\end{tabular}

Table 2. Descriptive Statistics

\begin{tabular}{|c|c|c|c|c|c|}
\hline & N & Mean & Std. Deviation & Minimum & Maximum \\
\hline Perception of Tourist & 202 & 3.3079 & 1.22614 & 1 & 8 \\
\hline Responses & 202 & 6.4554 & 2.73203 & 1 & 10 \\
\hline
\end{tabular}

Table 3. Kruskal-Wallis Test Ranks

\begin{tabular}{|c|c|c|c|}
\hline & Perception & N & Mean Rank \\
\hline \multirow{4}{*}{ Tourist Perception } & Workability & 81 & 755 \\
\cline { 2 - 4 } & Increase visitor's patronage & 83 & 81.50 \\
\cline { 2 - 4 } & Increase in infrastructure & 57 & 213.53 \\
\cline { 2 - 4 } & Unique environment & 183 & 431 \\
\cline { 2 - 4 } & Attraction & 179 & 431 \\
\cline { 2 - 4 } & Increase in goods and services & 81 & 431 \\
\cline { 2 - 4 } & Accessibility to the site & 147 & 431 \\
\cline { 2 - 4 } & Security of the area & 98 & 431 \\
\cline { 2 - 4 } & Low cost of tour & 85 & 641.98 \\
\cline { 2 - 4 } & Popularity & 129 & 641.98 \\
\cline { 2 - 4 } & Recommended for another tourist & 112 & 641.98 \\
\hline
\end{tabular}

Table 4 reveals the Kruskal-Wallis statistic $\mathrm{x} 2(\mathrm{df}=10)$ $=769.783 ; \mathrm{p}<01)$. The result shows that the Kruskal-Wallis value of 769.783 is significant at 0 levels lower than the 05 levels set for this study. As a result, the null hypothesis stands rejected indicating that tourists' perceptions of Kwa Falls vary significantly.

Table 4. Test Statistics ${ }^{\mathrm{a}, \mathrm{b}}$

\begin{tabular}{|c|c|}
\hline & Perception \\
\hline Chi-Square & 769.783 \\
\hline Df & 10 \\
\hline Asymp. Sig. & 0 \\
\hline
\end{tabular}

a. Kruskal Wallis Test

b. Grouping Variable: Responses
The second hypothesis states that there is no significant variation in patronage status in the study area across the years. We also use the Kruskal-Wallis test to test this hypothesis. We used the data in Table 5 for the analysis. While Table 6 shows the descriptive statistics of the data set used for the study. Table 7 shows the mean rank of patronage across different years; the result obtained in 2011 indicates the mean rank $=14.50$. It increased to 22.50 in 2012, 30.50 in 2013. However, there was a decrease from 2016 to 2020. 2020 has the least means of patronage $=2.5$ positionable. Table 8 shows that the number of tourists visiting Kwa Falls varies significantly across different years. The chi-square value obtained was significant at a value lower than the limit $05 \times 2 \quad(d f=9)$ $=390 ; \mathrm{p}<01$. As a result, the null hypothesis stands rejected, demonstrating that patronage status varies significantly across the years. 
Table 5. Annual patronage level of the study area

\begin{tabular}{|c|c|c|}
\hline Year & $\begin{array}{c}\text { Number of } \\
\text { patronages }\end{array}$ & Percentage \\
\hline 2011 & 361 & 10 \\
\hline 2012 & 382 & 10 \\
\hline 2013 & 448 & 12 \\
\hline 2014 & 509 & 14 \\
\hline 2015 & 488 & 13 \\
\hline 2016 & 406 & 11 \\
\hline 2017 & 366 & 10 \\
\hline 2018 & 328 & 9 \\
\hline 2019 & 284 & 8 \\
\hline 2020 & 80 & 2 \\
\hline Total & 3652 & 100 \\
\hline
\end{tabular}

Table 6. Descriptive statistics

\begin{tabular}{|c|c|c|c|c|c|}
\hline & $\mathrm{N}$ & Mean & Std. Deviation & Minimum & Maximum \\
\hline patronage & 40 & 91.4000 & 29.29321 & 20 & 127 \\
\hline year & 40 & 2015.5000 & 2.90887 & 2011 & 2020 \\
\hline
\end{tabular}

Table 7. Kruskal-Wallis Test Ranks

\begin{tabular}{|c|c|c|c|}
\hline & year & N & Mean Rank \\
\hline \multirow{4}{*}{ patronage } & 2011 & 4 & 14.50 \\
\cline { 2 - 4 } & 2012 & 4 & 22.50 \\
\cline { 2 - 4 } & 2013 & 4 & 30.50 \\
\cline { 2 - 4 } & 2014 & 4 & 38.50 \\
\cline { 2 - 4 } & 2015 & 4 & 34.50 \\
\cline { 2 - 4 } & 2016 & 4 & 26.50 \\
\cline { 2 - 4 } & 2017 & 4 & 18.50 \\
\cline { 2 - 4 } & 2018 & 4 & 10.50 \\
\cline { 2 - 4 } & 2019 & 4 & 6.50 \\
\cline { 2 - 4 } & 2020 & 4 & 2.50 \\
\cline { 2 - 4 } & Total & 40 & \\
\hline
\end{tabular}

Table 8. Test Statistics

\begin{tabular}{|c|c|}
\hline & Patronage \\
\hline Chi-Square & 390 \\
\hline Df & 9 \\
\hline Asymp. Sig. & 0 \\
\hline
\end{tabular}

a. Kruskal Wallis test

b. Grouping variable: year

The findings of the study indicate that the ecotourism site is still viable. Tourism services and infrastructures are lacking and in poor supply. The patronage level decreases, though people still patronize the area because the environment is unique while socio-economic benefits are absent. Hence, patronage and socio-economic benefits are inextricably linked. The study reveals that the site is still attractive to tourists. Researcher affirmed in their studies that destination attractiveness is the main thrust of tourism and without which the tourism industry would be practically nonexistent $[31,32]$. However, despite the attractiveness, tourism support services are still below expectations.

However, [33, 34] in their studies support the findings of this study that ecotourism attractions are the fastest-growing tourism industry and a generator of benefits, but that its feasibility and development are site-specific and remain unknown in many regions. The weighted index of support services and infrastructure in the study indicated that accommodation, electricity, water supply, and transport services were in poor supply, affecting tourism activities. Others such as access roads, food and beverages, and tour services were the only visible support services though not in high stores. These services are necessary to attract the preference of tourists. The government at all levels in Nigeria has attempted to identify and promote ecotourism locations and infrastructure, according to the report [2], yet, in age-old community-based eco-destinations, the attractions, activities, facilities, and visitor satisfaction levels have yet to be identified and stay low key. Studies conducted by [7, 9] affirms that tourism support services offer crucial functions and services to tourists. With a lack of support services at eco-tourism sites, there will be limits to patronage at the site and the tourism potentials for Kwa Falls to flourish as a tourism destination will be reduced. The result further shows that from 2016 to 2020, there was a significant drop in the number of people going to the sites. On average, the number of people going there decreases by $16 \%$ each year. This study is supported by $[34,35]$. The researchers noted that if a destination can suit the demands of tourists, the more the goal is likely to be chosen as a preferred destination.

As more tourists visit a destination, the impact is likely to be felt $[1,33]$. The study revealed limited infrastructural development in supply. This study supports the research conducted by $[17,32]$ that tourism destinations have incredible power on tourists' choice, expectations and satisfaction, intention to revisit, and perceptions. The hypothesis of this study shows variation in tourists' perception and patronage of the study area.

\section{Conclusions}

The study examined the assessed tourism viability status of Kwa Falls ecotourism site of Aningeje rural community, Cross River State, Nigeria. The study concludes that the turnover of tourists over some time shows that the study area is a viable site. The study further indicates that people are still visiting the site because it is still unique and attractive, though it has not grown. After all, it is still in need of investment because some essential facilities and support services are either unavailable or in insufficient supply at the location. Undoubtedly, the study reveals that 
between 2016 and 2020, there was a decrease in patronage, which makes the site unable to generate employment, revenue to the communities and government, expansion of the business and attraction of other related companies as expected. However, it has the potential to generate socio-economic benefits. Thus, the attractiveness of the area determines the perception of the tourists and the satisfaction they receive, which affects patronage.
Our results recommend that the government and other stakeholders revitalize the Kwa Falls tourism attraction by providing subvention and other required support services and facilities. The study will make the site useful to potential investors bringing in investment to boost the area. We, therefore, conclude that Kwa Falls ecotourism site is a site of interest that attracts people for niche and general tourism over a while.

\section{Appendix}

\section{QUESTIONNAIRE}

Dear Respondents,

Please, this questionnaire is to enhance data collection for a study/research on "Tourism Viability Status of Kwa

Falls Ecotourism Site of Aningeje Rural Community, Cross River State, Nigeria". It is for Academic purposes only. Hence, the information provided will be treated with the utmost confidentiality. Also, it will take less than 10 minutes to fill it, your response will ease the compilation of data for the research.

Thank You

Dr (Mrs.) Violet Eneyo

Researcher

Instruction: Please, tick the correct answer or write the appropriate answer in the spaces provided.

(1) Age of respondent: (a) 18-30years [ ] (b) 31-40years [ ] (c) 41-50 years [ ] (d) 51-60 years (e) 61-70years [ ] (f) 71 years and above [ ]

(2) Gender: (a) Male [ ] (b) Female [ ]

(3) Country of Origin. State/Province.

(4) Marital status: (a) Single [ ] (b) Married [ ] (c) Divorced [ ] (d) Widow [ ] (e) Widower [ ]

(5) Educational Background: (a) No formal education [ ] (b) Primary [ ] (c) Secondary School [ ] (d) Tertiary Education [ ] (e) Post graduate [ ]

(6) Occupation: (a) Civil/Public Servant [ ] (b) Farming [ ] (c) Trading (d) industrialist [ ] (e) Consultant [ ] (f) Unemployed [ ] (g) Others [ ] specify.....

(7) How many times have you visited Kwa Falls tourism site?

(8) Will you still want to visit the sites in future? (a) Yes [ ] (b) No [ ] (c) I don't know [ ]

(9) What do you think of Kwa Falls tourism Site (Please tick in appropriate box as 'yes'; 'No' or 'Indifferent')

\begin{tabular}{|l|r|l|l|l|}
\hline S/N & Tourist Perspective & Yes & No & Indifferent (I don't know) \\
\hline a & Kwa Falls is working effectively (Workability) & & & \\
\hline b & Many People like coming to the site (Patronage) & & & \\
\hline c & There is increase in Infrastructure & & & \\
\hline d & The area is Unique environment & & & \\
\hline e & The area is very attractive (Attraction) & & & \\
\hline f & Increase in goods and services & & & \\
\hline g & Accessibility to the site & & & \\
\hline h & Security of the area & & & \\
\hline i & Low cost of tour & & & \\
\hline j & The area is well known around the world (Popularity) & & & \\
\hline k & I Recommend the site to others & & & \\
\hline
\end{tabular}

1) Do you think there should be improvement in some area? (a) Yes [ ] (b) No [ ] (c) I don't know [ ]

2) Which of the area do you thinks critically needs improvement? (a) Tour Guide [ ] (b) security [ ] (c) Accommodation (d) facilities [ ] (e) Support services (e.g drinking spot, restaurant, car hire etc.) [ ] (f) Environment [ ] $(\mathrm{g})$ Others [ ] specify. 


\section{REFERENCES}

[1] Grilli, G., Tyllianakis, E., Luisetti, T., Ferrini, S., \& Turner, R. K. "Prospective tourist preferences for sustainable tourism development in Small Island Developing States". Tourism Management, Vol. 82, pp. 104-178. 2021

[2] Amalu, T. E., Otop, O. O., Ojugbo, P. A., Omeje, V. U., \& Duluora, E. I.. "Recreation centre potentials for tourism development in Calabar, Cross River State, Nigeria". GeoJournal, Vol. 84 No. 6, pp. 1627-1643, 2019.

[3] Roseta, P., Sousa, B. B., \& Roseta, L. "Determiners in the consumer's purchase decision process in ecotourism contexts: a Portuguese case study". Geosciences, Vol. 10, No. 6, PP. 224, 2020.

[4] Bassey, F. O., Arrey, M. E. V., \& Ibe, C. E. "Private Sector Remittances and Tourism Development in Calabar, Cross River State". European Journal of Hospitality and Tourism Research, Vol. 7, No. 4, pp. 1-16, 2019

[5] Bassey, S. A.Technology, "Environmental Sustainability and the Ethics of Anthropoholism". Przestrzen Spoteczna (Social Space), Vol 21, pp. 85-109, 2020.

[6] Effiom, V. A. "Impact of honeypot development in the tourism sector in Cross River State: a case study of Calabar Metropolis". Journal of Tourism and Heritage Studies, Vol. 3, No. 2, pp. 85-97, 2012

[7] Amalu, T. E., Otop, O. O., Oko, U., \& Oko-Isu, P. E.. "Spatial distribution and patronage of Ecotourism attractions in Enugu State, Nigeria". Sustainable Geoscience and Geotourism, Vol. 2, No. 1, pp 1-15, 2018.

[8] Eja, E. I., \& Effiom, V. A. "Environmental implications of Tinapa Business Resort development on the catchment communities, Nigeria". Journal of Environment and Earth Science, Vol. 4, No. 2, pp. 73-77, 2014.

[9] Amalu, T. E., Otop, O. O., Duluora, E. I., Omeje, V. U., \& Emeana, S. K. "Socio-economic impacts of ecotourism attractions in Enugu state, Nigeria". GeoJournal, Vol. 83, No. 6, pp. 1257-1269, 2018.

[10] Oladeji, S. O., Awolala, D. O., \& Alabi, O. I. "Evaluation of sustainable ecotourism practices in Oke-Idanre Hills, Ondo-State, Nigeria". Environment, Development and Sustainability, pp. 1-29, 2021.

[11] Bassey, S., Orji, M., \& Afolabi, O. "An Overview of Materialistic and Unified app.roach to Man-Nature Relationship". GNOSI: An Interdisciplinary Journal of Human Theory and Praxis, Vol. 3, No.3, pp. 17-28, 2020.

[12] Boley, B. B., \& Green, G. T. "Ecotourism and natural resource conservation: the "potential 'for a sustainable symbiotic relationship". Journal of Ecotourism, Vol. 15, No. 1, pp. 36-50, 2016

[13] Cohen, E. "Bullfighting and tourism". Tourism Analysis, Vol. 19, No. 5, pp. 545-556, 2014.

[14] Dennis, O. "Ethics of Posterity for Environmental Development of the Niger Delta". GNOSI: An Interdisciplinary Journal of Human Theory and Praxis, Vol.
3, No. 3, pp.83-96, 2020.

[15] Adamu, A., Yacob, M. R., Radam, A., Hashim, R., \& Adam, S. U. "Economic valuation of ecotourism resources in Yankari game reserve, Bauchi Nigeria". Procedia Environmental Sciences, Vol. 30, pp. 139-144, 2015.

[16] Ijeomah, H. M., Alarape, A. A., \& Ogogo, A. U. "Ecotourism potentials of Plateau State, Nigeria: A monitoring survey". Asia Pacific Journal of Tourism Research, Vol. 16, No. 2, pp. 153-166, 2011.

[17] Awaritefe, O. "Motivation and other considerations in tourist destination choice: A case study of Nigeria". Tourism Geographies, Vol. 6, No. 3, pp. 303-330, 2004.

[18] Eja, E. I., \& Effiom, V. A. "Environmental implications of Tinapa Business Resort development on the catchment communities, Nigeria". Journal of Environment and Earth Science, Vol. 4, No. 2, pp. 73-77, 2014.

[19] Egbai O. O., Oba D. O., Ambe B. A., Abang P. O., Eneyo V. \& Ocheche C. A. "Agro-ecological Influence on the nutrient status and physico-chemical dynamics of the ultisols of rural Ehom, Cross River State, Nigeria". Environment and Ecology Research, Vol. 9, No. 4, pp. 204 208, 2021. DOI: 10.13189/eer.2021.090408

[20] Alexander, E. J., \& John, E. "Multimedia GIS of Tourism Sites in Cross River State". Unpublished M. Sc. Project Report Presented to the Department of Geoinformatics and Surveying, Faculty of Environmental Studies, University of Nigeria, Enugu Campus, 2015.

[21] Ajake, A. O. "Tourism marketing strategies performance: evidence from the development of peripheral areas in Cross River State, Nigeria". GeoJournal, Vol. 81, No.4, pp. 641-656, 2016

[22] Tunde, A. M. Harnessing tourism potentials for sustainable development: A case of Owu Water Falls in Nigeria. Journal of sustainable Development in Africa, Vol. 14, No. 1, pp. 119-133, 2012.

[23] Arowosafe, F., Akinwotu, O., Tunde-Ajayi, O., Omosehin, O., \& Osabuohien, E. "Push and pull motivation factors: a panacea for tourism development challenges in Oluminrin waterfalls, Nigeria". Journal of Policy Research in Tourism, Leisure and Events, pp. 1-12, 2021.

[24] Hvenegaard, G. T. "Using tourist typologies for ecotourism research". Journal of Ecotourism, Vol. 1, No. 1, pp. 7-18, 2002.

[25] Sharma, P., \& Nayak, J. K. "Testing the role of tourists' emotional experiences in predicting destination image, satisfaction, and behavioral intentions: A case of wellness tourism". Tourism Management Perspectives, Vol. 28, pp. 41-52, 2018.

[26] Eneyo, V.B., Oba, D.O., Ochiche, C.A., Essien, D.A. \& Antai, A.S. "Economic Impacts of Curfew Imposition on the Nightclub Industry in Calabar Metropolis, Nigeria. African Journal of Hospitality, Tourism and Leisure, Vol 10, No. 3, pp. 955-971, 2021. DOI: https://doi.org/10.46222/aj htl.19770720-142.

[27] Ekong, M. O. \& Eneyo, V. B. "The aesthetics value of plastics in carnival Calabar costume designs, Nigeria". World Environment Journal, Vol. 2, No. 1, pp. 73-94, 2018.

[28] Nicolaides, A. "Sustainable ethical tourism (SET) and rural 
community involvement". African Journal of Hospitality, Tourism and Leisure, Vol. 9, No. 1, pp. 1-16, 2020.

[29] Eneyo, V. B., Anim, O. A. \& Edward, J. E. "Assessing plastic wastes generation by eateries in Calabar, Nigeria". World Environment Journal, Vol 2, No. 1, pp. 95-106, 2018.

[30] Mustafa Aziz Amen, Hourakhsh A. Nia, "The Effect of Centrality Values in Urban Gentrification Development: A Case Study of Erbil City," Civil Engineering and Architecture, Vol. 8, No. 5, pp. 916-928, 2020. DOI: 10.13189/cea.2020.080519.

[31] Maghsoudi, M., Moradi, A., Moradipour, F., \& Nezammahalleh, M. A. "Geotourism development in world heritage of the Lut Desert”. Geoheritage, Vol. 11, No. 2, pp. 501-516, 2019.

[32] Font, X., Torres-Delgado, A., Crabolu, G., Palomo Martinez, J., Kantenbacher, J., \& Miller, G. "The impact of sustainable tourism indicators on destination competitiveness: the European Tourism Indicator System". Journal of Sustainable Tourism, pp. 1-24, 2021.

[33] Nugroho, P., \& Numata, S. “Changes in residents' attitudes toward community-based tourism through destination development in Gunung Ciremai national park, Indonesia”. Tourism Recreation Research, Vol. 46, No. 3, pp. 403-421, 2021.

[34] Nugroho, P., \& Numata, S. “Changes in residents' attitudes toward community-based tourism through destination development in Gunung Ciremai national park, Indonesia". Tourism Recreation Research, Vol. 46, No. 3, pp. 403-421, 2021.

[35] Lim, W. M., \& To, W. M. "The economic impact of a global pandemic on the tourism economy: the case of COVID-19 and Macao's destination-and gambling-dependent economy". Current Issues in Tourism, pp. 1-12, 2021 